\title{
New Paradigms of the Fashion System
}

ISSN: 2578-0271

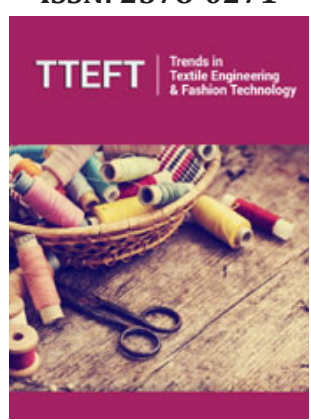

*Corresponding author: Doutora Graça Guedes, Escola de Engenharia/EngineeringSchool, Universidade do Minho, Campus de Azurém, 4804-533 Guimarães Portugal, E-mail: mgg@det.uminho.pt website: http://www.det.uminho.pt

Submission: 慍June 20, 2019

Published: 侮June 24, 2019

Volume 5 - Issue 3

How to cite this article: Graça Guedes. New Paradigms of the Fashion System. Advancements Bioequiv Availab.5(3). TTEFT.000611.2019.

DOI: 10.31031/TTEFT.2019.05.000611.

Copyright@ Graça Guedes, This article is distributed under the terms of the Creative Commons Attribution 4.0 International License, which permits unrestricted use and redistribution provided that the original author and source are credited.

\section{Doutora Graça Guedes*}

Escola de Engenharia/Engineering School, Universidade do Minho, Campus de Azurém, 4804-533 Guimarães Portugal, E-mail: mgg@det.uminho.pt website: http://www.det.uminho.pt

\section{Opinion}

The fashion system is now widely discussed in scientific circles and media outlets that refer to mountains of garbage, river pollution, gas emissions, and their impact on the greenhouse effect. Abuses and bad practices are reported that reveal the most evident lack of respect for human rights in general and those of workers in particular.

The sweatshops lost their power to mobilize public opinion face to companies' behaviors that reveal to be in the origin of disasters that even the short memory of men can forget.

When we look around, however, there are mountains of rubbish of all natures, rivers, seas and marine life are severely affected by both industrial and organic pollutant discharges, carbon dioxide emissions continue to overshadow the best efforts to reduce the environmental impact of human societies.

The fashion system is considered to be responsible for a significant part of the negative environmental impact we inflict on the planet every day. However, when we observe our surroundings objectively, we notice that most of the garbage we dispose of every day seldom contains any textiles or garments.

The bulk of the waste comes from the food industry, and we religiously continue to buy and dispose of after purchasing a significant component of the cost of many products: packaging.

When we analyze in detail the individual, family and social life in the today's world, it is clear that throughout the twentieth century the economies were oriented towards the growth of the respective GDP supported by the production, that is, by the consumption. The significant increase in the quality of life of populations, which we are striving to achieve, has led to the democratization of access to consumption, made possible by the reduction of market prices, achieved by the relocation of production and the globalization of the market.

The first world democratized consumption and encouraged developing countries first to offer incentives for the installation of multinationals in their territories and then to invest in their industries and support exports.

In the 90s the result of this orientation of the world economy was more than evident. Consumption had become overwhelming, voracious and thirsty: its decimated forests, polluted rivers, and seas, made the air of many cities unbreathable, encouraged greed and corruption everywhere.

The desired well-being of the population began to have poorly defined contours, for even in the most advanced societies the number of the homeless nevertheless continued to increase to the present.

Fashion could not fail to keep up with the consumerist movement that has taken hold throughout society and the global economy.

Across the globe, the impacts of consumerism grew and became overwhelming. At the end of the $\mathrm{XX}^{\text {th }}$ century, the prospects for the evolution of the situation became profoundly negative and the environmental and climatic crisis irreversible. 
Complaints of environmentally damaging practices emerged associated with virtually all productive sectors. The perverse impacts of abusive labor practices, especially in states with low labor costs, led to the development or reinforcement of movements oriented towards corporate social responsibility and the gradual but sustained increase in the percentage of consumers who started to adopt conscious consumption practices.

Curiously, fashion has become a subject of heated discussion and sharp criticisms that, although more than justified, have surpassed in visibility other more pressing problems for society and the environment. When we wonder about the reason for this phenomenon, we can find many answers or justifications.

One of the reasons may be that fashion is visible, accessible and understandable to the general population, integrates their daily lives and arouses their interest: fashion is close to people, it is a part of their lives even if there is no active and committed demand for it.

When we reflect on how dressing became Fashion, and how fashion has spread softly across society, we observe the transformation of a basic need into a sociocultural practice to impress the other, feel good, manifest a social status or an ideological position. Fashion performs functions focused on the domain of the various secondary human needs such as belonging, esteem, communication, and aesthetics.

The symbolic function of fashion has made it an instrument available and easily manipulated at the user level. The importance of fashion to the general public was evident in the diffusion that fashion information knew, especially from the ' 90 s, from when one after another, the generalist stockings began to publish information about fashion, or about fashion and design, either in regular editions or in periodic special supplements. Everywhere, fashion has seen its presence become unavoidable. So, its sins became more visible than those of the other sectors merely because of the law of proximity.

Let us take a look at the impact of the three crises we face at the beginning of this century: the environmental, social, and economic crises. The need to address the three crises at the same time leads societies to pursue practices that ensure sustainability, i.e., the maintenance or improvement of people's quality of life in a market environment where growth does not depend on systematic increases in production or consumerism. Sustainability is now frequently discussed on the bases of the Triple Bottom Line Principle: social, economic and environmental sustainability.

The consumer society thus knows the beginning of its end. Fashion followed this whole process. It was even in its origin, contributed to movements and protests. It launched support actions, occasional other systematic, with populations, disadvantaged groups of workers, and regions exploited by multinationals. Fashion was the protagonist of endless activities, initially assumed with political and ideological focus and, progressively, assumed as "mission" and "vision" by companies that understood the advantage they could get from it to differentiate their market brands.
The concept of ethical fashion was developed and consolidated over the second half of the twentieth century. In the beginning, it assumed several dimensions: fair trade, intervention fashion, green fashion, organic fashion, cruelty-free fashion, eco fashion, and other approaches ethics in the fashion system. In the first decade of the new century, we witnessed the proliferation of new ethical brands. The creation of the Ethical Fashion Forum in London in 2005, which was formalized in 2006 with 20 partners from four continents, adopted the three dimensions of fashion, or 3Ps (People, Planet \& Profit), which corresponds to the principle of the Triple Bottom Line advocated by the theories of Sustainability: Society, Economy and Environment.

The fashion system is infiltrated by environmentalist ideologies and practices and social responsibility, both by companies and consumers. The movement progressively increased and throughout the second decade of this century, there is a general convergence around the objectives and strategies centered on the environment, ethics, and social responsibility. Many new brands find opportunities for differentiation in the new market conditions, and research in the social sciences goes through the themes of sustainability in its various aspects, wardrobe studies, trends in ethical consumption, among others.

The movements multiply and involve the generality of stakeholders and the public of the fashion system. Rapid and global dissemination of new trends has taken place, and fashion and market trends are beginning to innovate, interweaving consumer demands and concerns (green materials and manufacturing processes, durability, proper labor practices and fair wages, among other) with the predisposition to prefer, at a given moment, certain aesthetic elements (styles, silhouettes, colors, patterns, patterns). The system is moving fast, and it is clear how most organizations are shaping themselves to follow market trends through the development of new products, new manufacturing processes, new materials, new approaches to business and communication practices.

Regardless of the perspectives on the global fashion system, it is evident that, in parallel with the new paradigms that affect the generality of society and the economy, three paradigms emerge of the profound changes that establish the practices and ideologies associated with fashion. The first of these paradigms is the change from futile to useful. The vision of the economic and social importance of fashion overcame the prejudice that claimed fashion to be the realm of futility and vanity.

States were not indifferent to the sector's contribution to GDP, export, and employment. The industries and all associated activities, internationalization, professional training, research, and fashion design receive governmental support and fashion weeks proliferate a bit throughout the world. Parallel to the relocation of production, there is a revaluation of "made in homeland", the incorporation in fashion collections of national cultural elements, as well as innovative materials and processes, by national designers and brands, who build a close link between tradition and 
modernity. The utility of the fashion value chain became evident and unquestionable, relegating to the past the view of fashion as a futile or pure manifestation of vanity.

Another paradigm that characterizes fashion today is durability. That is, the fashion product has shifted from rapid obsolescence to a desired long-life cycle. The product should look good over several seasons, and be recoverable if damaged, renewed and, when discarded, used by others (sold or offered), processed into a new product or recycled. The trend is to reduce the number of items purchased and increase the respective unit value.

An argument goes up against this paradigm: the fact that the market still buys a significant amount of low-price items. The economic crisis originated in the USA in 2008 first spread among the more advanced states and later to the New Industrialized Countries, namely the BRICS. The fall in national GDPs resulted in the reduction of the average household income and a significant increase in unemployment rates. This situation led consumers to reduce expenditure. Regardless of the wishes of many consumers, family budgets required them to buy low-price products, which kept low-cost fashion sales at significant levels. However, this is not a phenomenon similar to the previous demand for fast fashion products.

The third paradigm concerns the changing of the sociocultural focus of fashion to a psychosocial perspective. Fashion translated the dominant culture of societies and defined the social stratus, the social class that individual belongs.

The dominant classes adopted styles and fashion elements that, in time, spread to the other classes, in a top-down movement. Throughout the last decades of the $\mathrm{XX}^{\text {th }}$ century, fashion proposals grew in quantity and diversity, the access to fashion brands democratized, the levels of formal education of the population increased, the access to information in real time (Internet) and the access to social networks covered a growing percentage of the population in most countries. At the beginning of the XXI ${ }^{\text {th }}$ century, the trend towards fashion personalization or the way fashion items were integrated/associated with one another by the wearer to produce a personal fashion image became apparent. Fashion diffuses no longer from the dominant classes but in a trickle-across movement: the trends emerge at any point in society and radiate to the other points, spontaneously. Fashion (concepts and collections launched by brands and designers in markets) become freely adopted and used as a form of affirmation of individuality, and as a way to communicate identity and personal values, depending mainly on the psychological structure of the individual in his or her social context.

The reality of fashion is dependent on values, attitudes, and lifestyles, constituting a form of self-expression and a code of communication. This view, dominant in Europe and the USA, spreads rapidly in societies where individual freedom is a core value. Although many societies do not share this value, the fact is that the world has become global, and the majority of the state's share a global and increasingly accessible information environment. The new realities, even if not adopted by some of them, become known and inevitably induce changes. Which, the future will tell.

In conclusion, fashion has now been appropriated by the individual who uses it and transforms it according to its limits and competences. The accessibility to fashion products, the available information on fashion and the performance of brands give consumers the power to define his/her "fashion" and choose the brands he/she prefers, assuming the power to declare what brands he/she values. The fashion companies align themselves with their market targets and offer them the values they manifest as determinants in their purchase decisions. On the other hand, new brands emerge, generated by the encounter between the market opportunities originating from these new values and the continuous flow of new materials and processes resulting from the intense R \& D activity, characteristic of the most competitive states.

Inevitably, the central concerns of societies emerge and find answers in the proposals of fashion brands, which adapt themselves in a fast and flexible way and find sustainable solutions adequate to the nature of their market proposals. The fashion system is still accountable for significant negative impacts at all levels. However, the fashion system is heavily fragmented and witnesses a profound change that reflects an implicit will of its most creative and dynamic agents, of all dimensions, to make the system a part of the solution and no longer a part of the problem.

It is an opportunity to declare: "La mode est morte! Vive la Mode! “

\section{Acknowledgment}

Project UID/CTM/00264/2019 of 2C2T - Centro de Ciência e Tecnologia Têxtil, funded by National Founds through FCT/MCTES".

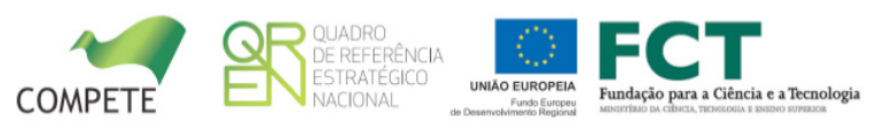

